\title{
A EXPOSIÇÃO 'O TEMPO DOS SONHOS' E A ARTE DOS ARTISTAS ABORÍGENES DA AUSTRÁLIA
}

\author{
Clay D'Paula ${ }^{1}$
}

‘Todos nós temos a mesma música; [mas com] melodias diferentes’ (Moko, 2004)

A arte aborígene da Austrália é um universo a parte. As obras produzidas por artistas contemporâneos nos oferecem uma abordagem inédita da linguagem visual, de estética exuberante e arrebatadora, revelando-se por meio de mapas mentais e espirituais. ${ }^{2}$

O reconhecimento e a validação da produção dos artistas aborígenes da Austrália não ocorreram do dia para noite. A transição de artesanato para artes visuais teve vários momentos e fases (D'Paula, 2017: 14-16). ${ }^{3}$ Contudo, a chegada de um professor de Sydney ao assentamento chamado Papunya, no centro da Austrália, mudaria o rumo e o destino de milhares de aborígenes daquele país-continente

\section{Um Professor Chega a Papunya}

Em 1971, Geoffrey Bardon (1940-2003) chegou ao assentamento, criado 10 anos antes pelo Governo australiano. Bardon ficou impressionado com os desenhos criados na areia pelas crianças que, mais tarde, foram incentivadas pelo professor a transpor os designs (linhas, arabescos e pontilhados) em papel, utilizando a tinta guache.

Bardon percebeu que os desenhos tinham formas de escritas pictográficas, como hieróglifos, e muito semelhantes aos petróglifos encontrados em rochas na Austrália. Ele também notara que os símbolos, carregados de significados, eram utilizados para a narrativa de histórias repassadas de geração em geração nas comunidades aborígenes (Bardon, 2006: 18).

Intrigado por todos esses emaranhados de símbolos e sinais, Bardon encorajou um grupo de homens adultos a criar um mural utilizando a sua iconografia tradicional e

\footnotetext{
${ }^{1}$ Clay D’Paula é especialista em arte Moderna e Contemporânea, com Masters em História da Arte na Universidade de Sidney, Austrália, e com estudos em arte indígena Australiana na Galeria Nacional de Nova Gales do Sul, também em Sidney.

${ }^{2}$ Nota da Organizadora: Texto original especialmente convidado para compor essa publicação.

${ }^{3}$ No catálogo da exposição 'O Tempo dos Sonhos: Arte Aborígene Contemporânea da Austrália' Djon Mundine, no seu entendimento, reflete sobre as sucessivas mudanças que passaram a arte aborígene.
}

Iluminuras, Porto Alegre, v. 19, n. 46, p. 424-435, jan/jul, 2018. 
mitológica ${ }^{4}$. Mais tarde, Bardon ofereceu suportes da arte tradicional europeia para que eles registrassem as suas histórias, através das representações simbólicas.

Os próprios artistas ficaram impressionados com a beleza dos resultados com o uso de tintas, pincéis, tábuas e telas. Isso causou uma sensação de orgulho cultural e, nos meses que se seguiram, a pintura desenvolveu-se em ritmo frenético no assentamento. Em um período de 18 meses mais de mil obras foram concebidas e cerca de 20 homens já se identificavam como artistas (McCulloch; McCulloch Childs, 2012: 19).

Desde então, a arte aborígene tem se diversificado de uma forma tão extraordinária que é praticamente impossível enquadrá-la em apenas uma categoria.

\section{A Presença de Artistas Aborígenes em Projetos de Arte Visual no Brasil}

Embora a exposição 'O Tempo dos Sonhos' apresente uma coleção mais diversificada, em termos de estilos estéticos, com presença na América Latina, já tivemos, no Brasil, outros projetos e exposições exibindo obras dos primeiros australianos. Em 1961, um grupo de artistas aborígenes participou da 6ª Bienal de São Paulo com 20 obras. Foi uma das primeiras exposições internacionais de grande prestígio a receber o trabalho desses artistas.

No catálogo digitalizado da segunda mais antiga de todas as bienais (Catálogo, 1961) é possível descobrir que grande parte das obras era de autoria desconhecida. Isso porque elas eram recolhidas durante as viagens missionárias ou nas visitas de antropólogos nas regiões norte e no centro da Austrália. Para eles, essas obras tinham status de objetos cerimoniais. Portanto, havia certo "desprezo" em relação à autoria e proveniência dessas obras de arte (Bardon, 2006: 8).

Muitas transformações ocorreram desde então. E para melhor. A participação de artistas aborígenes em eventos prestigiados da arte contemporânea internacional e em museus de renome é cada vez mais frequente. Logo, reconhecimento e autoria tornaramse um tema muito importante. A lista das instituições que exibem a arte aborígene no patamar das artes visuais é imensa. Portanto, continuo a deter-me nos eventos registrados em catálogos e pela mídia no Brasil.

\footnotetext{
${ }^{4}$ O resultado foi uma Mural, pintando em 1971, da escola em Papunya, na qual Bardon ensinava. A arte do mural contava 'O Sonhar das Formigas de Mel', a mitologia mais importante do Centro da Austrália (Bardon, 2006: 19)
} 
Em 1983, outros dois artistas aborígenes estiveram presentes na da $17^{\mathrm{a}}$ Bienal de São Paulo. São eles Clifford Possum Tjapaltjarri (1933-2002) e Uta Uta Tjangala (1926 - 1990). Possum é representado com duas obras na exposição 'O Tempo dos Sonhos', sobre a qual discorrerei em seguida. Os dois artistas tiveram a oportunidade de participar de outras exposições internacionais em um patamar em que poucos de Papunya conseguiram alcançar (Catálogo, 1983).

A Pinacoteca do Estado de São Paulo apresentou, em 2002, a exposição The 'Native Born: Arte Aborígene da Austrália'. Obras compiladas no centro-norte da Austrália. $^{5}$

Em 2014, mais de 40 obras de arte de vários artistas aborígenes atravessaram o oceano para participar do 'Uluru Internacional Festival' (Uluru Festival Internacional) no Reinassance Hotel São Paulo. As obras foram instaladas no saguão do hotel. Quatro delas serviram de inspiração para o chef Grant Croft - que veio da Austrália especialmente para o festival - e para o chef Thomas Leão, que liderava a cozinha do estabelecimento. Juntos, eles analisaram as obras para a elaboração de pratos. ${ }^{6}$ Também emparelhados com obras de arte aborígene, cinco rótulos da vinícola Bremerton localizada no Sul da Austrália - proporcionaram uma experiência sensorial para os convidados.

Depois de visitar São Paulo, a coleção se dirigiu para o Rio de Janeiro. Até então, não encontramos nenhum registro de outra exposição de arte aborígene no Rio. As telas saíram do saguão do Renassance Hotel para os espaços do Pop-Up Urca Urbana, em Botafogo. O projeto tomou corpo de mostra, não mais um festival, como aquele realizado em São Paulo, e recebeu o título 'Narrativa Heróica: Arte Aborígene Contemporânea da Austrália'.

\section{A exposição 'O Tempo dos Sonhos: Arte Aborígene Contemporânea da Austrália'}

A arte aborígene contemporânea não é uma réplica, nem uma cópia ou imitação, mas, uma transformação revolucionária que inovou e renovou o acervo imemorial da expressão artística dos primeiros australianos.

\footnotetext{
${ }^{5}$ Mais informações sobre a exposição podem ser obtidas em: http://www.saopaulo.sp.gov.br/eventos/artepinacoteca-do-estado-mostra-arte-aborigine-da-australia/

${ }^{6}$ Mais informações sobre o festival gastronômico e a desconstrução das obras de arte aborígene podem ser encontradas em: http://www.guiagphr.com.br/novidadesMercadoDetalhe.asp?iid=10633
} 
A exposição ' $O$ Tempo dos Sonhos: Arte Aborígene Contemporânea da Austrália ${ }^{77}$ apresenta, para o público brasileiro, 79 obras de arte da tradição artística contínua mais antiga do planeta.

Entre outras, o público poderá apreciar as bark paintings (pinturas em entrecasca de eucalipto), esculturas, pôsteres históricos, gravuras e pinturas, criadas a partir de elementos terrosos e tinta acrílica, as quais compõem a maior parte da coleção.

Essas pinturas apresentam composições intricadas, feitas a partir de uma paleta luminosa e exuberante. Embora algumas delas possam ser associadas à abstração, ao minimalismo ou ao expressionismo, as linhas e superfícies que as compõem simbolizam caminhos e jornadas dos ancestrais que, decodificados nas pinturas, levitam entre o físico e o espiritual. Essas obras de arte também podem ser caracterizadas como imagens gráficas ou ilusão óptica de incontestável qualidade estética. Para alguns apreciadores são as histórias, de cada pintura, que impressionam. Mas para outros, o encantamento e o fascínio surgem do impacto visual com o encontro de cada obra de arte aborígene.

As obras selecionadas para a exposição pertencem ao acervo da Coo-ee Art Gallery, a galeria de arte aborígene mais tradicional da Austrália, atuante no mercado internacional das artes há mais de 30 anos.

Para adicionar mais vigor e representar a diversidade de estilos dos artistas aborígenes, os curadores do projeto acrescentaram obras de colecionadores particulares. Dificilmente teremos no Brasil uma coleção de arte indígena da Austrália tão pujante e significativa.

A coleção da exposição 'O Tempo dos Sonhos' é de qualidade inquestionável porque reúne 78 obras de artistas que expressaram a simbologia mítica da tradição contínua aborígene, viva há mais de 30 mil anos, desde a criação de desenhos rupestres encontrados nas rochas da Austrália até a arte contemporânea aborígene como a conhecemos hoje. Entre os artistas que figuram na exposição, estão os precursores e fundadores do Movimento de Arte Aborígene na Austrália e aqueles de maior prestígio

\footnotetext{
${ }^{7}$ A exposição chegou em São Paulo em 2015 para celebrar o Autrália Now. Esse foi um festival artístico realizado em várias cidades brasileiras pelo departamento de Relações exteriores da Austrália. O objetivo dessa ação foi estreitar laços culturais e comerciais com o Brasil. A exposição abriu em março de 2015 na CAIXA Cultural São Paulo. Depois disso, o projeto visitou a CAIXA Cultural Fortaleza, a CAIXA Cultural Rio de Janeiro, a CAIXA Cultural Brasília e a Casa FIAT de Cultura. Até o fechamento deste texto, a exposição está programada para visitar mais quatro cidades brasileiras antes de seguir viagem para o Chile e Argentina. Mais informações sobre o projeto e sua itinerância na sua própria página na internet: https://www.facebook.com/otempodossonhos/
} 
internacional. Os trabalhos simbolizam o período Golden Age of Aboriginal Art (a Idade do Ouro da Arte Aborígene). Porém, a produção artística, nas mais de 100 cooperativas espalhadas por toda a Austrália, hoje encontra-se a todo vapor. A cada ano, os artistas inovam em termos estéticos e aprofundam as narrativas culturais em suas obras de arte.

\section{Expoentes da Arte Aborígene da Austrália}

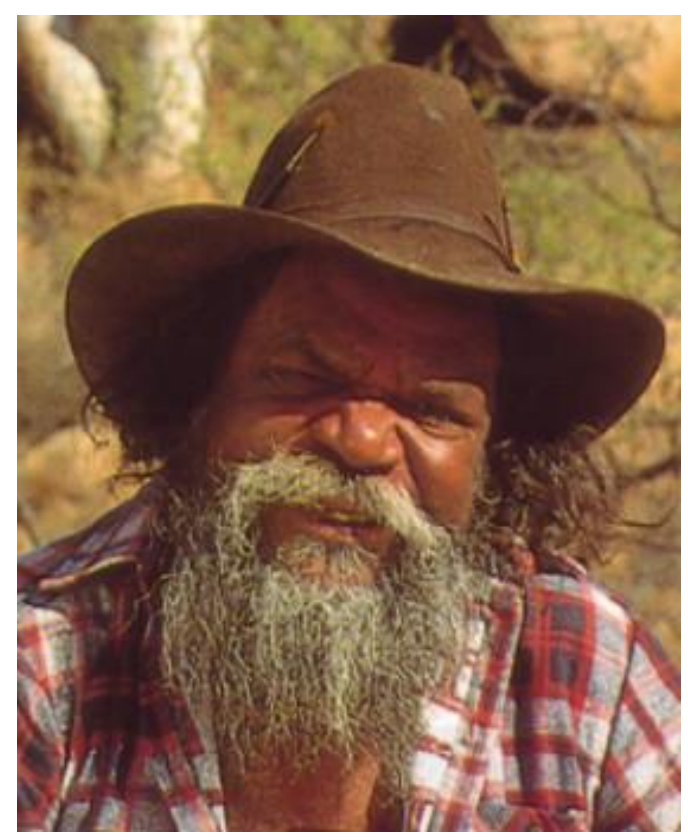

Imagem 1: Clifford Possum Tjapaltjarri. Cortesia Coo-ee Art Gallery

Clifford Possum Tjapaltjarri é reconhecido como um dos fundadores do Movimento de Arte Aborígene, que teve sua gênese no assentamento de Papunya. O grande marco foi a criação da cooperativa Papunya Tula Artists Pty Ltd, fundada em 1972 e incorporada como empresa em 1975. Mais de 10 anos se passaram para o surgimento de outras cooperativas (McCulloch e McCulloch Childs, 2012: 30).

Clifford é representado na exposição com duas obras em 'O Tempo dos Sonhos'. Uma delas é $O$ Sonhar de Possum, uma pintura, feita com tinta acrílica, de 1993. Além de criar pinturas memoráveis, o artista é considerado um divino colorista e uma característica peculiar de suas telas é a aplicação de finos pontilhados de tinta para encobrir imagens sagradas e secretas.

Os trabalhos de Clifford tornaram-se clássicos no contexto da arte contemporânea australiana. Clifford está entre os 10 artistas campões de venda. Em julho de 2007 teve a 
obra Warlugulong, pintura sobre tela, leiloada por 2, 4 milhões de dólares australianos na Southeby’s, em Melbourne, Austrália (McCulloch e McCulloch Childs, 2012: 8).

Assim como Clifford vários artistas passaram a empregar materiais modernos na criação de suas obras, a exemplo da tinta acrílica e de telas. Foi justamente por meio dessa junção de suportes e materiais ocidentais com o conjunto de designs de sua cultura, que os artistas aborígenes conseguiram inovar e revelar sua linguagem e sua estética. Esses artistas usaram como temática de suas obras as representações de sua cosmologia e a intensidade e o poder de sua espiritualidade.

Ao apreciar a arte aborígene contemporânea, podemos questionar a ideia de que a arte ocidental de base europeia seja superior a outras formas de expressão artística. Logo, sugiro acatar o fato de que todas as comunidades humanas estão habilitadas a expressarem-se artisticamente. Isso porque no horizonte da diversidade, não cabem verticalidades etnocêntricas.

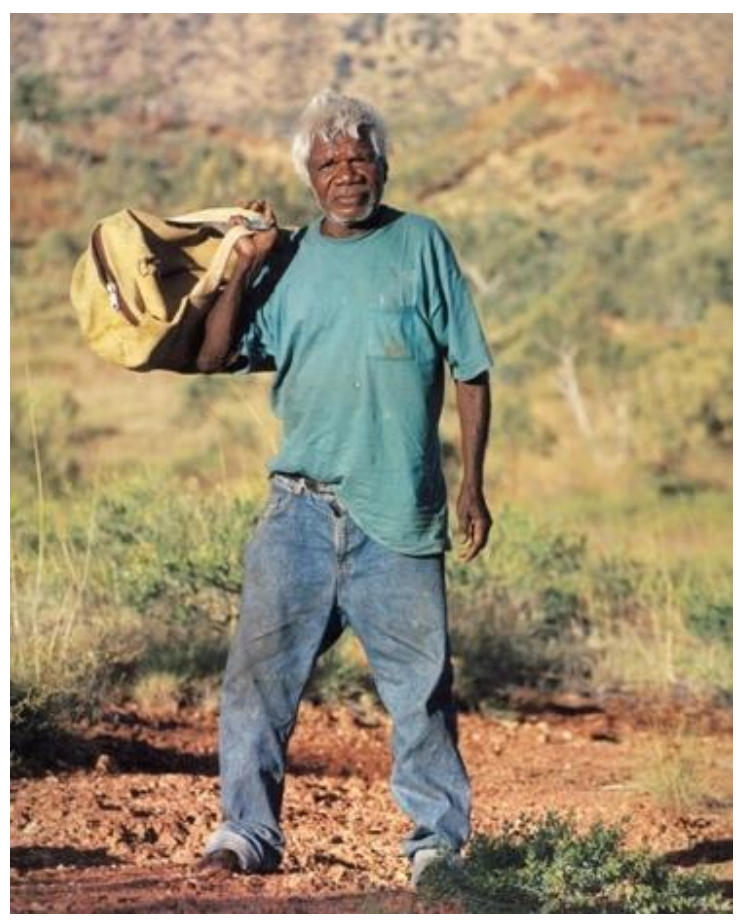

Imagem 2: Rover Thomas no deserto a Austrália. Cortesia Coo-ee Art Gallery

Os artistas aborígenes também utilizam elementos terrosos e naturais na composição de suas obras de arte, principalmente os artistas da região de Kimberley. Antes de Rover Thomas (1926-1998), o mundo da arte nunca tinha visto ocres tão potentes e vibrantes . O artista ficou conhecido como o "colorista selvagem". Em suas 
pinturas os tons de marron compõem com o branco e com o preto, este, retirado do carvão vegetal.

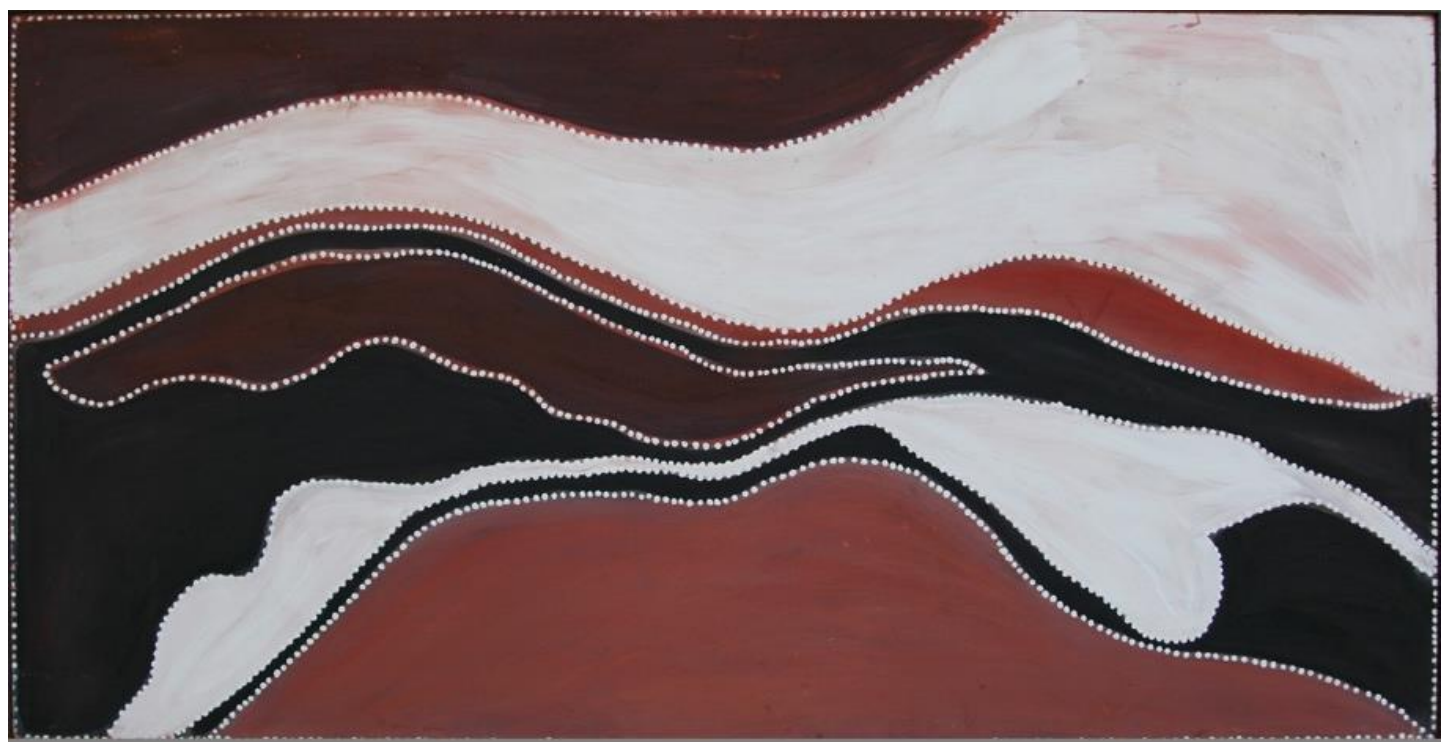

Imagem 3: Obra Solo Argiloso, Estrada de Canning Stoc', de 1985, do artista Rover Thomas. Fonte: Cortesia Coo-ee Art Gallery, Sidney, Austrália

A arte de Thomas provou ser um divisor de águas no desenvolvimento da arte aborígene. Ele redefiniu conceitos da paisagem australiana em suas obras e desafiou a criação artística aborígene como um todo, além de abrir caminhos para artistas que viriam depois dele. A exposição o 'Tempo dos Sonhos' traz duas obras do artista que representou a Austrália na Bienal de Veneza em 1990. Uma delas é Solo Argiloso, Estrada de Canning Stock, de 1985. Essa é uma obra típica dos artistas da região de Kimberley: densas camadas na cor ocre e marrom, com formas serpenteadas e delineadas com pontinhos brancos.

Outra artista notável da arte aborígene australiana é Emily Kame Kngwarreye (1910c - 1996). Emily colocou Utopia no mapa do mundo da arte e fez com que a região se tornasse um celeiro de produção artística. Ela inspirou e incentivou uma legião de artistas mulheres aborígenes a pintar. A artista ficou mundialmente conhecida por começar a sua carreira aos 79 anos de idade, quando a maioria dos artistas nessa idade diminuem, radicalmente, a sua produção. Emily, pelo contrário, trabalhava todos os dias com tanto vigor e aptidão que impressionou galeristas, colecionares e críticos de arte. Os batiques (técnica de tingimento em tecido) trouxeram reconhecimento imediato para a 
artista. Mas, de acordo com Emily, esse suporte não oferecia a liberdade que ela tanto procurava. Introduzida à tinta acrílica e às telas Emily encontrou-se no paraíso da arte. Produziu ao longo de sua carreira, um período de oito anos, cerca de 4.000 pinturas. Suas obras vendem mais no mercado secundário do que qualquer outro artista aborígene.

O oeuvre de Emily exibe uma diversidade de estilos, obras gestuais - distintiva de qualquer outro artista aborígene - e coloração especial. A sua produção artística chegou a ser comparada às obras de masters europeus e americanos: Claude Monet, Bridget Riley e Jackson Pollock - apenas para citar alguns. Emily participou de inúmeras exposições e Bienais.

Assim como Rover Thomas, representou a Austrália na Bienal de Veneza de 1997. Ela expôs lado a lado com Kandinsky, Mondrian e Picasso no Museu de Arte Moderna, em Nova Iorque. A artista deixou um legado de proporções míticas para a Austrália e os povos aborígenes.

A obra Sem Título, de 1992, pode ser apreciada na exposição 'O Tempo dos Sonhos'. Nesse trabalho, Emily registrou as estações do ano. É uma obra que oferece, ao observador, um reducionismo de cores e uma visão mais holística da artista no seu fazer. 


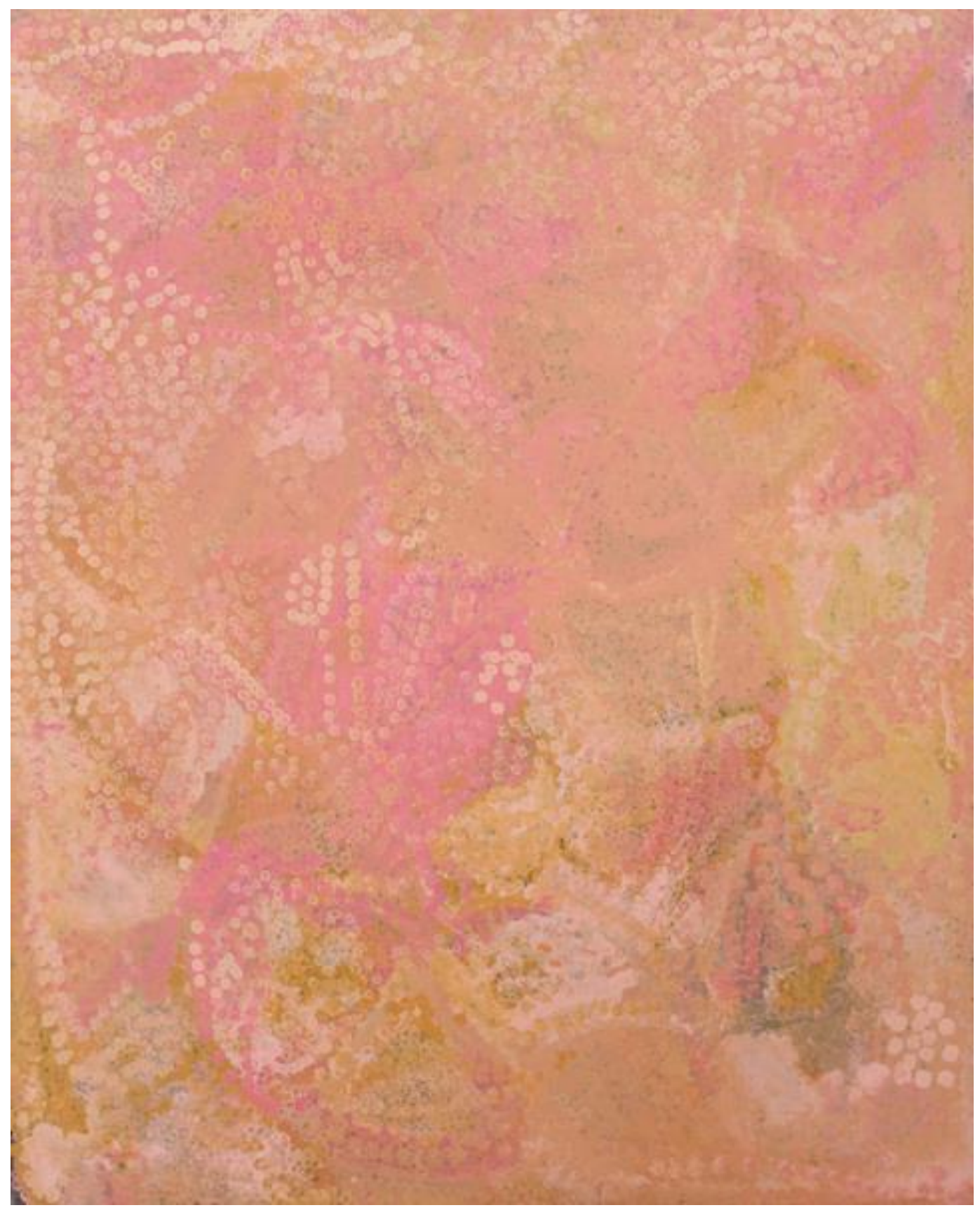

Imagem 4: Obra Sem Título, 1992, da artista Emily Kame. Fonte: cortesia Coo-ee Art Gallery, Sidney, Austrália

Iluminuras, Porto Alegre, v. 19, n. 46, p. 424-435, jan/jul, 2018. 


\section{Uma Arte de Grande Poder}

Embora os artistas aborígenes utilizem elementos tradicionais de sua cultura em sua criação artística, a arte aborígene está incluída na produção atual. É a filosofia indígena australiana aplicada à arte contemporânea. A arte aborígene é sinônimo de

protesto. É preciso compreender que os elementos tradicionais não naufragam na contemporaneidade, mas, estão implícitos na voz dos artistas, que falam e protestam pelo meio de suas obras.

\section{O Terror tem a Pele Branca e o Coração Humano}

Com a chegada dos colonizadores europeus, em 1878, houve uma mudança drástica no modo de vida dos povos indígenas da Austrália. A princípio, essas alterações foram catastróficas: a dizimação de populações tribais através de doenças e a desapropriação imposta aos sobreviventes. Ao longo do século XIX e por muito no século $\mathrm{XX}$, os novos governantes e proprietários das terras impuseram uma forma de vida dura aos povos indígenas australianos e chegou-se a pensar na dizimação total das populações.

Contudo, os povos aborígenes não se dobraram a essas mudanças. Contra todas as expectativas, os nativos reagiram a elas com superação - renovar-se às circunstâncias impostas, traçar um caminho notável e de caminhar em uma nova era. E a arte foi um dos pilares que sustentaram essa mudança. Por meio da arte os artistas aborígenes desenvolveram uma relação intercultural. Com suas obras de arte e sua estética, única e inigualável, um novo diálogo foi criado com a população não-aborígene.

Apesar de os povos aborígenes estarem em contato com sociedades ocidentais nos últimos 200 anos, eles não veem a Europa como o centro do universo. Embora a utilização de materiais ocidentais esteja presente na criação de suas obras, não existe relação com o minimalismo ou a abstração da arte ocidental, como fazem referência os críticos de arte, por exemplo. O centro do universo para um artista aborígene é onde ele nasceu e viveu. O encontro com tintas e telas ocidentais é apenas físico, não intelectual. É preciso reconhecer o trabalho artístico indígena como um produto cultural e original de seu meio e de sua tradição. 


\section{Considerações Finais}

E inegável que a exposição 'O Tempo dos Sonhos' apresenta obras de alto valor estético: uma sinfonia de símbolos, cores, formas e texturas. Os artistas são músicos que criam no improviso. Eles não utilizam desenhos preparatórios, nem instrumentos de medida - como um compasso e uma régua - para a criação de suas obras de arte. Não existe uma pressão para a criação, para a invenção. Eles são artistas livres, libertos do peso teórico e acadêmico que carregam os artistas ocidentais.

No nosso mundo ocidental nós temos a vontade natural, que reflete em nosso comportamento, de classificar coisas, de congelar e de fragmentar o tempo. A ideia de presente, passado e futuro e período contínuo no qual os eventos se sucedem não existe na cultura aborígene. O que existe é o estado de "ser" e "viver" em comunhão com os elementos existenciais que os cercam. Os artistas da exposição 'O Tempo dos Sonhos' proporcionam ao observador a alma e o espírito, extraídos da mente de artistas que se comunicam com o mundo natural e numa cosmologia que ultrapassa o nosso entendimento. É uma arte estoica e fiel ao conhecimento. É uma arte de manifestação: da resistência, da resiliência e afirmação.

Com a sua arte os artistas lutam para a sobrevivência de sua língua, de sua cultura e de sua própria existência. Não podemos nos esquecer que desde a chegada nos europeus línguas morreram e gerações foram roubadas.

Hoje a arte dos artistas aborígenes são "armas do bem”. Uma vez que na cultura aborígene não existe a linguagem escrita, os artistas utilizam suas obras para protestar e reclamar suas terras desapropriadas à força.

A exposição 'O Tempo dos Sonhos: Arte Aborígene da Austrália' é um projeto, uma exposição política. Por trás das obras que encantam os olhos e afagam a alma encontram-se gritos de dor, de angústia, de desespero, de luta pela sobrevivência. Por outro lado, existe nas obras algo que nos mantêm mais vivos que o sangue que corre em nossas veias ou o alimento que mata a nossa fome - a esperança. Um sopro de esperança não apenas para populações indígenas, mas, para toda a humanidade. A filosofia dos povos indígenas, seja presente em histórias e ou na arte, é pura "água viva". 


\section{Referências Bibliográficas:}

BARDON, Geoffrey. Papunya Tula - Art of the Western Desert. Sydney: Gecko Books, 2006.

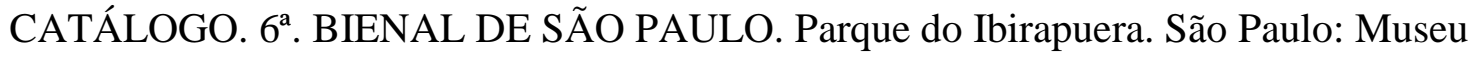
da Arte Moderna, Setembro aS Dezembro, 1961. Disponível em:

http://www.bienal.org.br/publicacao.php?i=4395. Acesso em: 20 de fevereiro de 2018.

CATÁlogo. 17a . BIENAL DE SÃO PAULO. São Paulo: Museu da Arte Moderna, Outubro a Dezembro, 1983. Disponível em:

http://www.bienal.org.br/exposicao.php?i=2334. Acesso em: 20 de fevereiro de 2018.

D’PAUlA, Clay. O Tempo dos Sonhos: Arte Aborígene Contemporânea da Austrália. Capítulo: A Austrália Branca tem uma História Negra. págs.14-16, Brasília, 2017.

McCULLOCH, Susan; McCULLOCH CHILDS, Emily. McCulloch's. Contemporary Aboriginal Art, the complete guide. Sidney: McCulloch \& McCulloch. Australian Art Books, 2012.

MOKO, Donald. Carta para Emily Rohr, Archivos da National Gallery of Victoria (NGV), 2004. 